Historic, archived document

Do not assume content reflects current scientific knowledge, policies, or practices. 



\section{THE NEW STRAWBERRY}

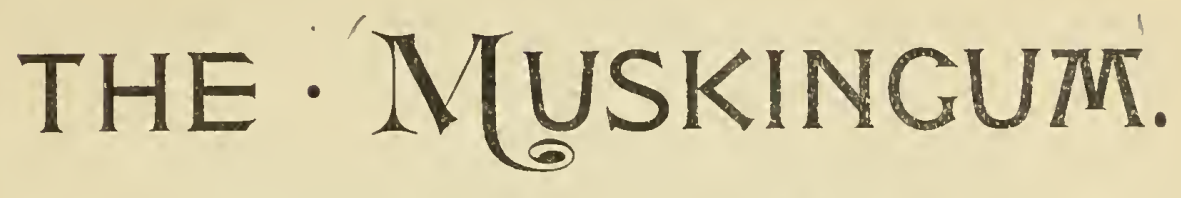

\section{It Driginater in MIuscingurn \\ Coxnty, Onio.}

In $188+$ this berry received the first prize and was named at the summer meeting of the State Horticultural Society, held at the Ixperiment Station, June I I, I 890 . We have been cultivating and testing this variety for about eight years, being better pleased with its hehavior each year, till it is now our nain cropper. It makes a large. perfect blossoni on good, stout fruit stems, and is very prolific in bearing, and in vigor and growth of plant is not surpassed by any. Never blights, scalds or burns in the leaf, no matter how lot or wet the weather. The berries are of large size, and continue large to the end of the season. In form, obtusely conical, but mostly round toward last of the season; yet few of the very largest are coxcon1l,. They ripen very evenly all over; the berries never scald or burn in the sun, and we have had them to hang on vines for several day's after ripening without spoiling. The berry is a very 11 ice, red, glossy color, with red flesh and of good flavor, which makes it a good berry for home use and the nost profitable market berry we have ever grown.

It is as productive as the Crescent, in quarts. In June, I890, one row made nearly as much money as two rows of Crescent with equal cultivation.

Pickers gather 200 quarts very easy a day, and would rather gather them than any other variety.

Last year (I891) was an off year on account of frost. Some of the pickers picked 200 quarts in a day at several pickings during the season.

We do not claim that it is entirely frost proof, but it escaped better than the Sharpless, Bidwell, Parker Farl and others, growing side by side.

The prices the past season ranged from 75 cents to \$1.25 more per bushel than the Crescent.

We consider it the most profitable herry we have ever grown. 


\section{- Testimonials. .}

Ohio Agriculteril, Experiment Station Bulietin, Argust, i8go.

(Page 217. )

Muskingum. (Perfect.) Originated with GRANT KEARNs, Zanesville, Ohio. Plant very vigorous, healthy and productive; berries conical, usually flattened, but regular in outline and uniform in size; color dark, glossy crimson; quality good. This variety has been on trial at the Station two seasons, and has proven satisfactory in every way. It is one of the most productive of the perfect flowering sorts, but being rather late in ripening it miglit not answer if used alone, to pollenize Crescent and Haverland. As compared with Enhance, the two are about equal in vigor and productiveness, and ripen at about the same time. In appearance the Muskingum excels the Enhance, and perhaps also in quality. A few plants were sent to Mr. CRAWFORD for trial, and he regards it as very promising. It will, no doubt, take high rank among perfect flowering sorts.

\section{BTLLETIX, OCTOBER, ISgI. (Page II7.)}

Muskingum. (Perfect.) This variety has been on trial several seasois, but is not introduced. It appears to have no serious faults, and is believed to be an acquisition of great merit. The plants are healthy, vigorous and productive, while the berries are uniform in size, large and attractive. Season, medium to late.

Ohio Agrictittral Station, Columbes, W. J. Greex, HorticenTURIST.

Columbus, September t. 189 I.

Grant Kearns, Zanesville, Ohio:

DEAR SIR:-The frost injured our strawbery blossoms so much that we cannot tcll much about the comparative merits of rarieties. Wre had but little fruit on Muskingum plants, but judging from what we had and from what we have seen of it in previous seasons, we can say that it is a very promising variety. The plants make a good, healthy growth, and are 
productive, while the berries average well in size and are of good color and quality. The variety has very decided merits. If we had a cut we should like to insert it in our report. Yours truly, W. J. Grenes.

I expect to be at your next horticultural meeting.

\section{J. J. Pittis \& Co., Produce Commission Merchants.}

CI,EVEI,AND, OHIO, October 22, I 890.

GRANT KFARNS, EsQ.

SIR:-The strawberries you shipped to us last June arrived in better conclition than any you had shipped us in previous seasons, although the season was rery wet and receipts, as a rule, were in bad order. We refer to herries of the Muskingum variety, which were of fine flavor and excellent quality. We can heartily recommend them as a good shipper.
Yours truly,
J. J. PítTs \& Co.

\section{F. R. Palmer \& Son, Horticulturists.}

Mansfield, Oilio, July 20, i8gi.

Mr. Grant Kearns, Zanesville, Ohio:

DEAR SIR:-The Muskingum plants you sent are growing nicely. We let a few blossonis set fruit and the berries were fine.

We think it will he a very valuable variety. Hope to be able to report favorably of it next year when it fruits.
Very respectfully,
F. R. PALMER.

\section{ZaNesville, OHio, January io, i 892.}

The Muskingum, as I have seen it grow on G. KEARns' farm, is a strong, healthy grower, perfect bloomer, and productive; berries large and very uniform in size and shape; moderately firm; ripens mid season and continues very late. For profit to the grower, one of the very best.

WESLEY EVANS.

CraWford's JULY REPORT ON STRAWBERRIES FOR 1890.

Muskingum.-From Zanesville, Ohio. This berry teceived the first prize and was named at the summer meeting of the State Horticultural 
Society held at the State Experiment Station on June I Ith. It is a variety of very great promise. It fruited here this year, and at this date there is not a spot of rust on its foliage. Besides being a great bearer it is of large size, and continues large to the end of the season. In form it is obtusely conical and nearly round towards the last. It is dark red and glossy, with red flesh, and its flavor is good.

I am located near by the originator of the Muskingum strawberry, Mr. GRANT KEARNS, and have had opportunties to watch its habits since its birth, which was in the year of 1884 .

I anl frank to say, that, as far as I know, it has but few equals and 110 superiors, and is in every way all that is claimed for it. Mr. KraRns has grown berries for a number of years, and is a good grower of this fruit, and his modesty prevents his sending out anything but a modest introduction of his first production of a new fruit.

S. R. MOORE.

\section{PIR IEES.}

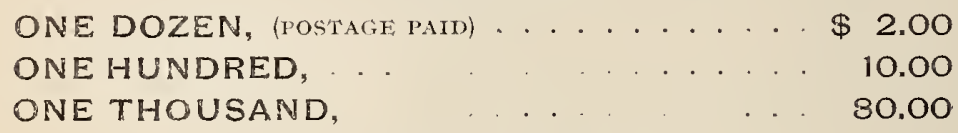

RACITNG FREE.

To unknown parties, one-ihird cash, to accompany order; balance C. O. D.

Send money by draft, money order or registered letter. ADDRESS,

\section{GRANT KEARNS,}

\section{Box 66, Zanesville, Muskingum County, Ohio.}

